\title{
A FINEMET-ötvözet tulajdonságváltozásának vizsgálata hagyományos, impulzusos és mechanikai feszültség alatt végzett hőkezelést követően
}

\section{Investigation of the property change in FINEMET alloy after conventional, pulse and mechanical stress annealing}

\author{
Szabó Attila, ${ }^{1}$ Sánta Róbert, ${ }^{2}$ Lovas Antal, ${ }^{3}$ Novák László ${ }^{4}$ \\ ${ }^{1}$ Dunaújvárosi Egyetem, Gépészeti Tanszék, Dunaújváros, Magyarország, szaboattila@uniduna.hu \\ ${ }^{2}$ Dunaújvárosi Egyetem, Gépészeti Tanszék, Dunaújváros, Magyarország, santarobert@uniduna.hu \\ ${ }^{3}$ Budapesti Müszaki és Gazdaságtudományi Egyetem, Közlekedésmérnöki Kar, Gépjármütechnológia \\ Tanszék, Budapest, Magyarország, antal.lovas@gjt.bme.hu \\ ${ }^{4}$ Kassai Müszaki Egyetem, Fizika Tanszék, Kassa, Szlovákia, ladislav.novak@tuke.sk
}

\begin{abstract}
In the present work the comparison of the effect of traditional, pulse and stress annealing is made by monitoring the important mechanical and magnetic properties of FINEMET type amorphous precursor alloy. The magnetic properties were determined from the shape of magnetization curve (coercive force, anisotropy) during various heat treatments and the mechanical properties were measured using brittleness test. The traditional heat treatments were performed in resistance furnace and the magnetic measurements were performed in astatic magnetometer. The pulse and stress annealing (as well as their combinations) were carried out inside in the magnetometer. The temperature of pulse heat treatments is regulated with the length of current pulse flowing through the sample. After each pulses the magnetization curves were measured in-situ, in the magnetometer.
\end{abstract}

Keywords: pulse heat treatment, FNEMET, amporphous, nano-crystalline, brittleness.

\section{Összefoglalás}

Jelen kutatómunka célja a hagyományos, az impulzusos és a mechanikai feszültség alatti hőkezelések hatásának összehasonlítása FINEMET típusú amorf ötvözeteken, a mechanikai és mágneses tulajdonságok változásának megfigyelésével. A mágneses tulajdonságokat a különböző hőkezelések során a mágnesezési görbe alakjából (koercitív erő, anizotrópia) határoztuk meg, a mechanikai tulajdonságokat törékenységi teszttel mértük. A hagyományos hőkezeléseket ellenállás-fütésű kemencében, a mágneses méréseket asztatikus magnetométerrel végeztük. Az impulzusos és a mechanikai feszültség alatti hőkezeléseket (valamint ezek kombinációit) a magnetométerben hajtottuk végre. Az impulzusos hőkezelés hőmérsékletét a mintán átáramló áramimpulzus hossza szabályozza. Minden impulzus után a mágnesezési görbéket in-situ meghatároztuk.

Kulcsszavak: impulzus-hőkezelés, FNEMET, amporf, nanokristályos, törékenység.

\section{Bevezetés}

Az elmúlt évtizedekben a Fe-alapú nanokristályos ötvözetek jelentős szerepet játszottak a lágymágneses anyagok előállításában. A kiváló jellemzőket a FINEMET $\left(\mathrm{Fe}_{73,5} \mathrm{Si}_{13,5} \mathrm{~B}_{9} \mathrm{Nb}_{3} \mathrm{Cu}_{1}\right)$, amorf szer- kezetű prekurzor ötvözet termikus bomlásával sikerült megvalósítani [1]. Feltételezések szerint a nanométeres a-Fe (Si) szemcseszerkezet alapvető szerepet játszik a kiemelkedő lágymágneses tulajdonságok kialakulásában [2]. Megjegyzendő, 
hogy az amorf fázis bomlásának kezdeti hőmérséklete ugyanabban a kristályosítási reakcióban is megváltoztatható, eltérő méreteloszlást eredményezve [3]. A legkisebb szemcseméret várhatóan akkor alakul ki, amikor a kristályosodás hőmérséklete a kérdéses ötvözet olvadáspontjának 50\%-a körül lesz [4]. A lágymágnesesség tükröződik a koercivitás mértékében, amely inverz kapcsolatot mutat több lágymágneses ötvözetben az átlagos szemcsemérettel. Ez a kapcsolat azonban a Fe-Si-B ötvözetekben a 100-1 nm átlagos szemcseátmérő-tartományban megszünik. Ezt a kivételes viselkedést a mágneses korrelációs hossz és a szemcse átmérője közötti egybeesésnek tulajdonítják. Bizonyos szemcsméret alatt a szemcsék már olyan kicsik lesznek, hogy kiátlagolódik a kristálytani anizotrópiájuk doménfal-mozgásra gyakorolt hatása, ezzel a koercitív erő csökkenést eredményezve [2].

A nanométer nagyságrendü szemcseméret azonban nem kizárólagos ok a kiváló lágymágneses jellemzők kialakulására. Csak azon nanokristályos ötvözetek mutatnak kiváló lágymágneses jellemzőket, amelyekben a nanokristályos szerkezetet üvegállapotú prekurzorból primer reakció útján állították elő [5]. Ez a reakció az első lépés a hipoeutektikus Fe-B ötvözet amorf fázisú bomlása során, illetve ez tekinthető a nanokristályos átalakulás kétlépéses mechanizmusa első fázisának a FINEMET $\left(\mathrm{Fe}_{73,5} \mathrm{Si}_{13,5} \mathrm{~B}_{9} \mathrm{Nb}_{3} \mathrm{Cu}_{1}\right)$ prekurzorokban [6]. Az említett átalakulást számos szerző tárgyalja [7-9]. Általános egyetértés van a kristályosodás első és második lépése szétválasztásának fontosságáról, mivel mágnesesen kemény fázisok jelennek meg a második kristályosodási lépcső során, kedvezőtlenül befolyásolva az ötvözet lágymágneses tulajdonságait. Ezen elválasztást megfelelő ötvözőelemek hozzáadásával valósítják meg. A csíraképző elem, pl. Cu hozzáadása (az a-Fe képződésének elősegítése) kiemelkedő jelentőséggel bír a csírák kialakulásának és homogén eloszlásának biztosítása szempontjából [10], de hozzájárul az a-hoz tartozó kristályosodási lépések elválasztásához, azaz az $\mathrm{Fe}(\mathrm{Si})$ és $\mathrm{Fe}_{3} \mathrm{~B}$ képződési hőmérsékletének szétválasztásához is. $\mathrm{A} \mathrm{Nb}$ hozzáadása hozzájárul a Fe3B intermetallikus vegyület kiválásának késleltetéséhez, elkerülve a mágneses keményedést [11]. Az ötvözetben a Si jelenléte biztosítja továbbá az üveges állapot általános stabilitását.

A hypoeutektikus Fe-B fémüvegekben az a-Fe nukleációjának hőmérsékletét a $\mathrm{Cu}$ hozzáadásával csökkentik [12, 13]. A Cu preferenciális oldhatósága az fcc $\gamma$-Fe környezetben kioltja a $\gamma$-Fe típusú szimmetriákat az amorf mátrixban, amelyek a mágnesezési folyamat során inaktívak, azaz gátolják a domének falának elmozdulását. A hőkezelés során a hőmérséklet emelkedésével a $\gamma$-centrumok először eutektoidos mechanizmuson keresztül bomlanak, mivel a Cu-diffúzió aktiválási energiája kicsi $[14,15]$. A vázolt mechanizmust a kísérletek is alátámasztják [6]. Ennélfogva önmagában ez a nukleációs jelenség a nanokristályos szerkezet kialakulását megelőzően is hozzájárul a koercivitás csökkentéséhez [13].

A hagyományos nanokristályosítást izotermikus hőkezeléssel hajtjuk végre körülbelül $540{ }^{\circ} \mathrm{C}$-on, 1 órán át, amikor a DO3 rendezett rácsú fázis képződik, amely a-Fe(Si) szilárd oldat, miközben az $\mathrm{Nb}$ és a $\mathrm{B}$ dúsul a maradék amorf fázisban. A közelmúltban impulzusos hőkezelésekkel, illetve mechanikai feszültség alatti hőkezelésekkel (a hőkezelés hosszirányú feszültséggel kombinálva) [16] végeztek kísérleteket a lágymágneses tulajdonságok testreszabása céljából.

Bár a vázolt módszerek az ipar számára sem ismeretlenek, a tulajdonságok befolyásolásának néhány részlete még megválaszolatlan. A koercivitás és a törékenység változásának, atomi szintű mechanizmusának ismerete a mai napig nem tisztázott. Ezen kérdések megértése áll jelen munka középpontjában.

\section{A kísérletek ismertetése}

\subsection{Anyagok, hőkezelések és mérési mód- szerek}

A kísérleteinkhez a jól ismert FINEMET-ötvözetet alkalmaztuk. A $10 \mathrm{~mm}$ szélességü, $30 \mu \mathrm{m}$ vastagságú mintákat mechanikus vágással 100 mm hosszúságúra állítottuk be. Az impulzusos hőkezelést az impulzushosszot változtatva, 10 A csúcsáram és $50 \mathrm{~Hz}$ frekvencia alkalmazása mellett hajtottuk végre. Az impulzus időtartama 0,08-0,12 másodperc között változott. A mintákat a fenti módszerekkel hőkezeltük, a hütési fázisban kényszerlevegős hütés nélkül. A becsült hütési sebesség körülbelül $100 \mathrm{~K} / \mathrm{s}$, a fütési sebesség körülbelül $1000 \mathrm{~K} / \mathrm{s}$ volt. A mágneses méréseket in-situ végeztük a hőkezelés során egy asztatikus magnetométer segítségével. A koercitív erőt $\left(\mathrm{H}_{\mathrm{c}}\right)$ a mágnesezési görbékből határoztuk meg, amelyeket minden egyes impulzus után ábrázolunk.

$\mathrm{Az}$ 1. ábrán példák találhatók a hőmérséklet időbeni lefolyására, amelyet különböző hosszúságú, különböző energiákat képviselő impulzusok okoznak. A mérés részleteit és az eredmények kiértékelését a [16] irodalom ismerteti. 


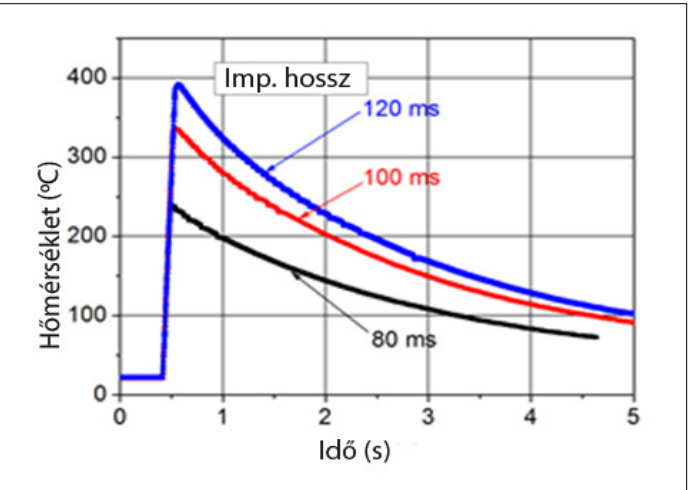

1. ábra. A mintahőmérséklet időfüggése különböző időtartamú impulzushosszakat követöen FINEMET-ötvözeten [16]

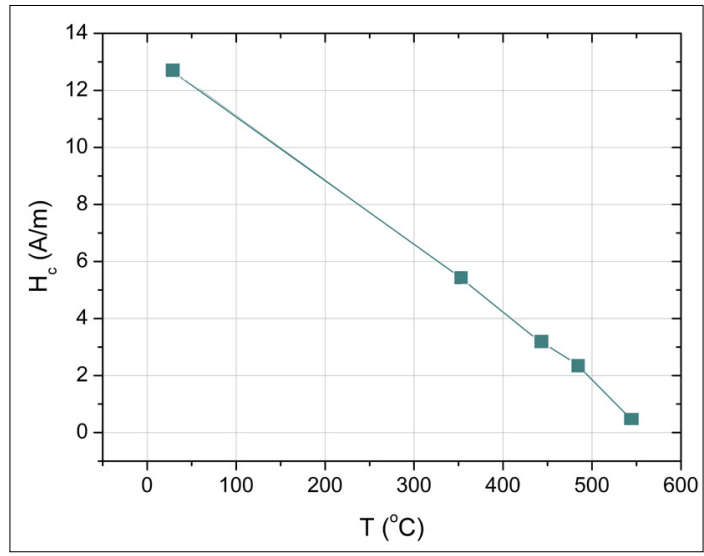

2. ábra. A koercitív erō (H) változása FINEMET prekurzor ötvözetben, 1 h idötartamú, különböző hőmérsékletü, izotermikus hőkezelések hatására [19]

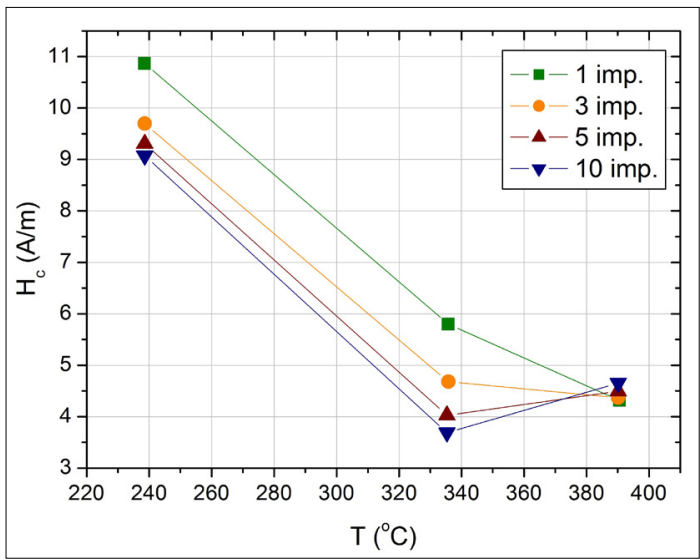

3. ábra. Összefüggés a koercitivitás és a különböző impulzusszám és impulzushossz által elért maximális hőmérséklet között
A repedés megindulásához szükséges relatív alakváltozást egyszerü hajlítási teszt alapján határozzuk meg. A vizsgálat során a d vastagságú szalagot két párhuzamos lemez között meghajlítjuk egy $\mathrm{r}=\mathrm{D} / 2$ sugarú félkörré, ahol $\mathrm{D}$ a két lemez közötti távolságot jelöli. A töréshez tartozó $\varepsilon_{\mathrm{f}}$-t a [17, 18]-ban leírt $\varepsilon_{\mathrm{f}}=\mathrm{d} /(\mathrm{D}-\mathrm{d})$ kifejezésből származtatjuk.

Kísérleteinkben húzó irányú mechanikai igénybevétel okozta feszültség alatti hőkezelést végzünk. Egytengelyü feszültség ( $\sigma=0,2$ és $4 \mathrm{MPa}$ ) alkalmazásával hagyományos, illetve impulzusos kezeléseket kombináltunk hosszirányú mechanikai feszültséggel a minta melegítésének időszaka alatt. A mintában a terhelőerőt a függőleges elrendezésű tekercstestben levő mintára akasztott súlyokkal ébresztettük.

\section{Eredmények}

\subsection{A koercitív erő hőmérsékletfüggése izo- termikus hőkezelések során}

A mágneses tulajdonságok változását az amorf nanokristályos transzformáció során több közlemény ismerteti $[6,18]$. A tipikus tendenciát a 2. ábra szemlélteti, ahol a FINEMET-minták $\mathrm{H}_{\mathrm{c}}$-jét ábrázoljuk az izotermikus (1 órás) hőkezeléseket követően. Ezt az eredményt tekintjük referenciatendenciának az impulzusos kezelések hatásának értékelése szempontjából.

A koercitív erő $\left(\mathrm{H}_{\mathrm{c}}\right)$ csökkenése két, egymást kissé átfedő fizikai folyamatból származik: a kis hőmérsékleti tartományban a $\mathrm{H}_{\mathrm{c}}$-csökkenés kizárólag a szerkezeti relaxációból származik $\left(\mathrm{T}_{\text {anneal }}<350^{\circ} \mathrm{C}\right)$, amely rövid távú kémiai rendet tartalmaz, és amelyben a kötés-újrarendeződés is történik a befagyott atomok között, hosszú távú diffúzió nélkül. A teljes $\mathrm{H}_{c}$-csökkenés több mint 50\%-a ebből a folyamatból származik. Ebben a hőmérsékleti tartományban nem észlelhető a kristálycsíra kialakulásának nyoma. $400^{\circ} \mathrm{C}$-on túl a további $\mathrm{H}_{\mathrm{c}}$-csökkenés a kristálycsírák kialakulásával és a nanokristályok növekedésével jár. Ebben a folyamatban a közepes távú átrendeződéssel járó diffúzió is részt vesz.

Ezekben az ötvözetekben a $\mathrm{H}_{\mathrm{c}}$ további, majdnem nagyságrendnyi csökkenése jellemző. Ezen a hőmérsékleti intervallumon belül nanométer méretű, DO3 típusú szemcseszerkezet fejlődik, amely $\mathrm{Fe}(\mathrm{Si})$ szilárd oldat. Ez a folyamat körülbelül $540{ }^{\circ} \mathrm{C}$-on befejeződik. Maga a $\mathrm{H}_{\mathrm{c}}$ a kristályosodás korai szakaszában még változatlan marad, éppen az ellenkező tendencia figyelhető meg a bináris fémüvegekben [20]. A szignifikáns 
csökkentést a $\gamma$-központok fokozott eliminációjával kell értelmezni az eutektoidos reakció révén a beragadt $\mathrm{Cu}$-atom által, így a Cu-atomoknak katalitikus hatása van a $\gamma$-centrumok eliminációjára, és ezáltal az fcc környezetekből kiinduló eutektoidos reakció elősegítésére.

A 3. ábrán a $H_{c}$ változását ábrázoljuk az impulzusos hőkezelések során alkalmazott, független impulzusok sorozatának növekvő csúcshőmérséklete esetén (lásd az 1. ábrát). Megállapítottuk, hogy a csúcshőmérséklet túlnyomórészt az impulzus hosszától függ (1. ábra), következésképpen a legnagyobb $\mathrm{H}_{\mathrm{c}}$-csökkenés a kísérletekben alkalmazott legmagasabb csúcshőmérsékleten várható. A 0,1 s impulzushosszon a csúcshőmérséklet közel $350{ }^{\circ} \mathrm{C}$. Egyetlen impulzus hatása a $\mathrm{H}_{\mathrm{c}}$-szuppreszszióra majdnem ugyanaz, mint az 1 órás, izotermikus hőkezelésé ugyanazon a hőmérsékleten, jelezve, hogy a mágneses feszültség-relaxáció rendkívül gyors folyamat, és hogy ezt feltehetően ennek a relaxációs mechanizmusnak a nemdiffúziós jellege okozza.

Ezt a megfigyelést támasztja alá a 4. ábrán öszszegyüjtött mérési sorozat is. Itt a $\mathrm{H}_{\mathrm{c}}$-csökkenést ábrázoljuk a különböző (növekvő) impulzushoszszokra (0,08 s, 0,10 s és 0,12 s). Ezeket a független méréseket in situ hajtottuk végre a magnetométerben. Figyelemre méltó, hogy a $\mathrm{H}_{\mathrm{c}}$ csökkenése elhanyagolható az impulzussorozat alatt, kivéve az első hőimpulzust. Az is megfigyelhető továbbá, hogy a csúcshőmérséklet (vagy az aktiválási energia nagysága) meghatározó szerepet játszik a $\mathrm{H}_{\mathrm{c}}$ kinetikájában. A szerkezeti relaxáció időszakában a $\mathrm{H}_{\mathrm{c}}$ csökkenése kizárólag a rövid távú, atomos átrendeződésekkel jár együtt ezekben a befagyasztott feszültségcentrumokban. Mivel az impulzusok csúcshőmérséklete elég nagy, ezen feszültségcentrumok száma gyorsan csökken.

\subsection{Impulzusos hőkezelések külső mágneses térben}

Longitudinális külső mágneses mezőt alkalmaztunk annak érdekében, hogy megvizsgáljuk a hőhatás és a külső mágneses mező közötti kölcsönhatást. A lágymágneses, gyorsan hütött szalagokban a mágneseztetés egyszerủ iránya a szalag hossza mentén történik. A magnetométer által létrehozott mágneses tér iránya a kísérletben párhuzamos a szalag egyszerủ mágnesezési irányával.

Ha longitudinális mágneses mezőt alkalmazunk a hőimpulzusok alatt, akkor a $\mathrm{H}_{\mathrm{c}}$-görbék meredeksége növekszik az impulzusszám függvényében, ami azt jelenti, hogy a longitudinális mező

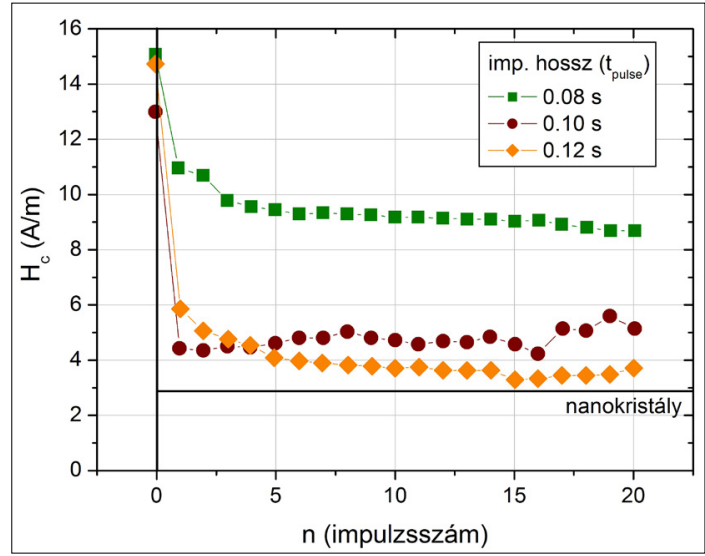

4. ábra. Koercivitásváltozás az alkalmazott impulzusszámmal szemben, eltérö impulzushossz esetén (csúcshőmérséklet)

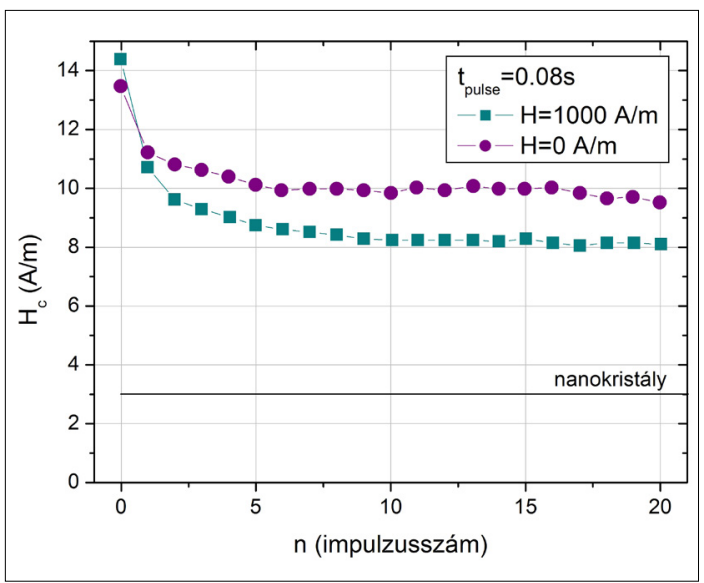

5. ábra. Az $1000 \mathrm{~A} /$ m-es mágneses mezö szerepe a $H_{c}$ alakulásában a 0,08 s hosszúságú impulzusok sorozatában

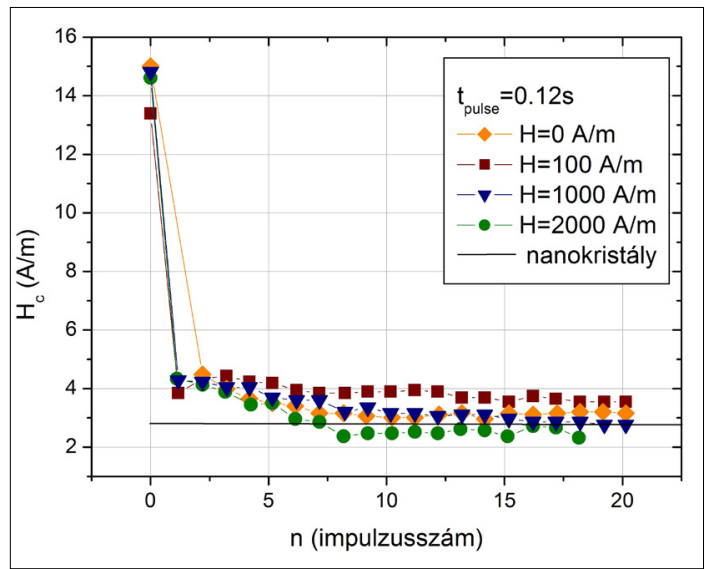

6. ábra. A térerősség hatása a Hc-re a 0,12 s hosszú impulzusok sorozata során 
(hasonlóan a hagyományos hőkezelésekhez) elősegíti a $\mathrm{H}_{\mathrm{c}}$-csökkenést (lásd a 6 . ábrát). Ebben a kísérletben 0,08 s-os impulzust alkalmaztunk. Ilyen körülmények között $\left(\approx 240^{\circ} \mathrm{C}\right.$ csúcshőmérséklet) a csíraképződést és -növekedést kizárjuk, csak a feszütségrelaxáció az oka a $\mathrm{H}_{\mathrm{c}}$-csökkenésnek. A hosszirányú mező szerepe hasonló a nagyobb, 0,1 s impulzushosszon (lásd a 7. ábrát), de egymást követő 0,12 s-os impulzusok után a Hc értéke megegyezik azzal, amelyet 1 órás, izotermikus hőkezelés után kapunk az ekvivalens, neki megfelelő, $\approx 400^{\circ} \mathrm{C}$ hőmérsékleten (lásd a 2 . ábrát).

\subsection{Impulzusos hőkezelések külső mágneses térben, mechanikai igénybevétel alatt}

Termodinamikai szempontból a fémüvegek egyfázisú, homogén kontinuumot képviselnek. Ennek ellenére sok fizikai tulajdonság jelentős mechanikai anizotrópiát mutat (a mechanikai tulajdonságok különbsége hossz- és keresztirányban, vagy a hidrogénelnyelés mechanikai válaszának különbsége a szalagfelületeken).

Ezek a tulajdonságok utalnak a szalagok gyártási technológiájából adódó, két oldalán eltérő helyi hűtés sebességei közötti különbségre. Feltételezhetjük a kapcsolatot a helyi hütési sebesség, illetve a feszültségcentrumok gyakorisága és eloszlása között, amely összekapcsolható olyan feszültségérzékeny tulajdonságokkal, mint a $\mathrm{H}_{\mathrm{c}}$. $\mathrm{Az}$ ilyen tendenciák felismerhetők a 7. ábrán, ahol a hajtóerőt a FINEMET-ötvözetek impulzusos hevítésének sorozata alatt figyeljük.

A mérést hosszanti mágneses mezőben és hosszirányú mechanikai igénybevétel mellett is elvégeztük. Amint a 7. ábra mutatja, az alapállapotú szalagok $\mathrm{H}_{\mathrm{c}}$-értéke (0 impulzus) kissé csökken, ha hosszirányú erőt vagy mágneses mezőt alkalmaztak a mérések során ennek az ötvözetnek a kis

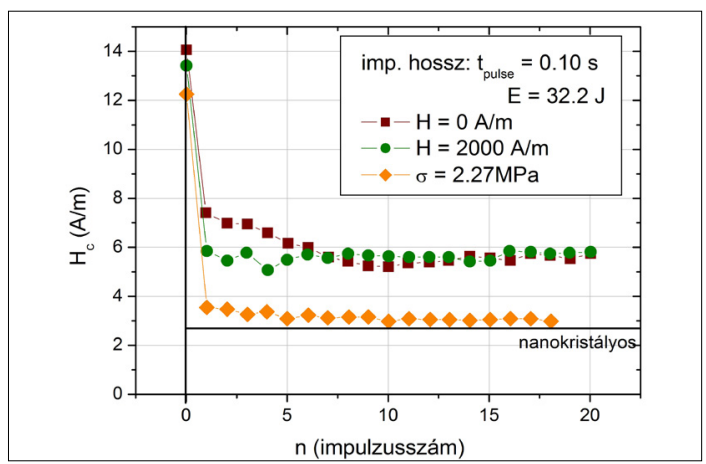

7. ábra. A koercitív erö $\left(H_{c}\right)$ változása 0,1 s-os impulzusok hatására longitudinális mágneses mező és mechanikai feszültség alkalmazása esetén pozitív magnetosztrikciója miatt. A hosszirányú mező és a terhelés szerepe nyilvánvaló. Figyelemre méltó, hogy a $\mathrm{H}_{\mathrm{c}}$ az alkalmazott terhelés miatt már az első impulzus hatására (csúcshőmérséklet $\approx 330^{\circ} \mathrm{C}, 0,1 \mathrm{~s}$ impulzushossz) közeledik a teljesen nanokristályosodott szerkezethez. A nanokristályos szerkezetnek azonban nyilvánvaló a hiánya ezen a hőmérsékleten.

\subsection{A fémüvegek elridegedésének eredete}

Számos atomi szintű mechanizmus hozzájárul a fémüvegek elridegedéséhez. A fémüvegek közötti jelentős, ridegségbeli különbség részben a különböző összetételből vagy a különböző termikus előéletből származik [21]. A Fe-alapú, gyorshütött állapotú fémüvegek ridegsége főként a metalloidtartalomból adódik, amely egyidejüleg biztosítja a megfelelő üvegképző képességet (főleg a B-, P- és Si-tartalom). Ezért a rugalmasság vagy a ridegség [18] főleg összetétel-specifikus az átmenetifém-metalloid alapú üvegekben, azaz nincs közvetlen kapcsolat a kristálymagok képződése és az elridegedés között. Jellemző példa a $\mathrm{Fe}_{100-\mathrm{x}} \mathrm{B}_{\mathrm{x}-}$ bináris rendszer: ha összehasonlítjuk a hipo- és a hipereutektikus fémüvegeket (kis és nagy B-tartalom), a hipereutektikus fémüvegek a tökéletesen röntgenamorf szerkezetük ellenére kevésbé szívósak (ridegebbek). Ennek oka a kovalens kötés jellege és a $\mathrm{Fe}_{100-\mathrm{x}} \mathrm{B}_{\mathrm{x}}$ fémüveg hipereutektikus régiójának növekvő B-tartalma. Általában a törékenység tendenciája közvetlen korrelációban van a lehütött Fe-B minták keménységével (HV) [21]. Elridegedést tapasztalunk továbbá a kristályosodás kezdetén is, amit a hajlítási vizsgálatok és a párhuzamosan elvégzett nagy felbontású diffrakciós vizsgálati technikák (TEM) is alátámasztanak.

Az elridegedés alakulásának elméleti kezelése az üvegképződést leíró, ún. szabad térfogat elméleten alapul [22, 23]. A makroszintű viszkozitásnak feltételeznie kell a viszkozitás $\eta(T)$ és az atomra eső átlagos szabad térfogat közötti kapcsolatot. $\Delta G_{m}$ az elmozdulás aktiválási energiája, $v^{*}$ a szabad térfogat kritikus ingadozása, $\gamma$ a 0,5 és 1 közötti geometriai tényező, $R$ a gázállandó, és a $C$ is egy állandó:

$$
\eta(T)=C R T \exp \left(-\frac{\Delta G_{m}}{R T}\right) \exp \left(\frac{\gamma v^{*}}{v}\right)
$$

A viszkozitás változásának ezt a makroszintű tendenciáját a gyorshűtött minta elridegedésének fenomenológiai háttereként tekintik. A [22, 23] szerint kapcsolat áll fenn a lehütött szabad térfogat összeomlásának kinetikája és az elridegedés között. Maga a szabad térfogat a hűtési se- 
bességtől függ, és ennek eredményeként a mintában vastagságirányú feszültséggradiens alakul ki.

A vázolt megfontolás szerint a rideg viselkedés kialakulása összefüggésbe hozható a melt spinning gyártási eljárás következtében értelmezhető hengeroldali felület és a szabad felület felületekhez közeli határrétegében értelmezhető szabad térfogat-különbség megszűnésével, amelynek hatása a minták hőkezelés során történő spontán deformációjában is megjelenik.

A vizsgált FINEMET-ötvözetek esetében a (mágnesesen és mechanikusan) kemény részecskék fejlődése nagy hőmérsékleten $\left(\mathrm{T} \approx 600^{\circ} \mathrm{C}\right)$ történik meg, tehát az elridegedés hirtelen növekedése (lásd a 8. ábrát) a relaxációból származik $\left(\mathrm{T} \approx 330^{\circ} \mathrm{C}\right.$ ).

A ridegség változását az impulzusszám függvényében a különböző impulzushosszokon a 9. ábra szemlélteti. A 0,08 s-os impulzussorozat

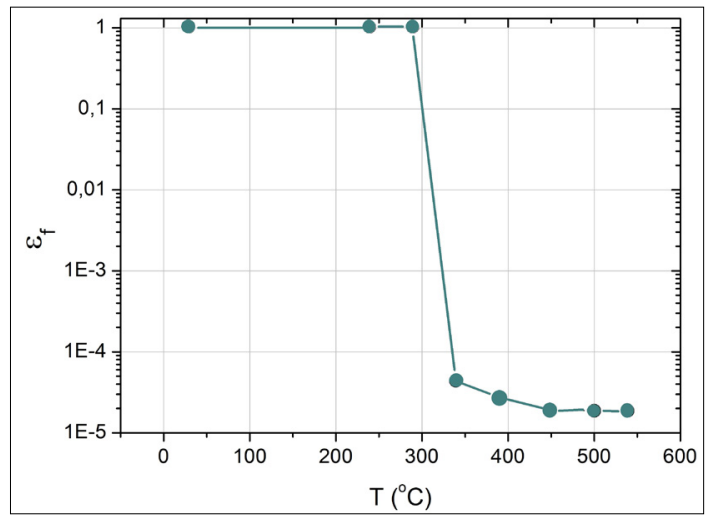

8. ábra. A FINEMET-minta elridegedése izotermikus hökezelések során

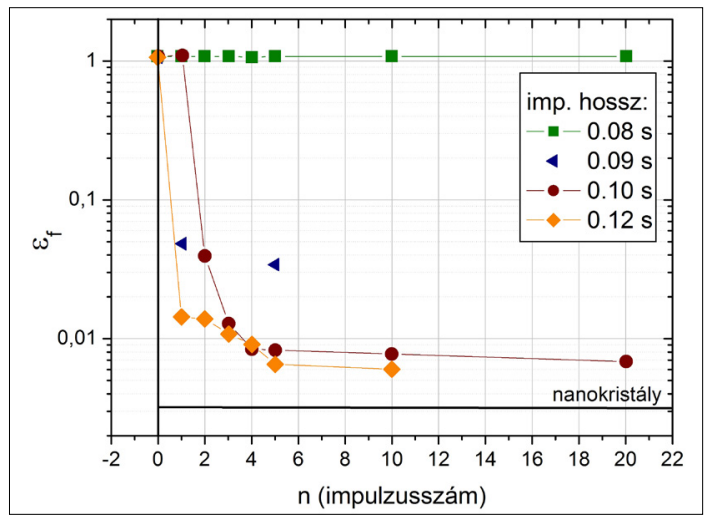

9. ábra. A FINEMET-minta törést okozó hajlítási alakváltozásának változása az impulzuszszám függvényében a különböző impulzushosszak esetén alkalmazása során (a maximális csúcshőmérséklet körülbelül $240^{\circ} \mathrm{C}$ ) a szalagok rugalmassága fennmarad az impulzussorozat teljes ideje alatt (20 impulzus), azaz elridegedés nem észlelhető. Ennek ellenére ugyanazon körülmények között szignifikáns $\mathrm{H}_{\mathrm{c}}$-csökkenés történik (lásd az 5. ábrát). Ezzel szemben, ha az impulzus hossza kissé megnövekszik (impulzus hossza 0,09 s, a csúcshőmérséklet $292^{\circ} \mathrm{C}$ ), akkor a rugalmasság megszünése már az első impulzus után megfigyelhető. Ahogy az impulzushossz megközelíti a 0,1 s-ot, a ridegség az izotermikus hőkezelés után kapott értékeket is megközelíti. A 8. és 9. ábra szerint a hőkezelés hőmérséklete meghatározó szerepet játszik az elridegedés mértékében, a hőkezelés időtartama csak másodlagos jelentőséggel bír. Megfigyelhető továbbá, hogy az elidegedés mértéke általában alacsonyabb az impulzusos hőkezeléseknél, mint az izotem hőkezelések esetén (lásd a 8. és a 9. ábrát).

\section{Következtetések}

A FINEMET-ötvözetek tulajdonságainak vizsgálata során összehasonlítottuk a hagyományos (izotermikus) impulzus- és mechanikai feszültség alatti hőkezelés hatását. Az impulzusos és a mechanikai feszültség alatti hőkezelést (valamint ezek kombinációit) magnetométerben hajtottuk végre, ahol a mágneses méréseket minden impulzus után, in situ végeztük. Az impulzusos hőkezelések hőmérsékletét az áramimpulzus hosszával szabályozzuk. A kísérletekben a koercitív erő $\left(\mathrm{H}_{\mathrm{c}}\right)$ csökkentését már a szerkezeti relaxációs fázisban is kimutathatjuk, azonban a $\mathrm{H}_{\mathrm{c}}$-csökkenés csak részleges kristályosodás után tapasztalható meg. A kutatás során az alábbi következtetéseket vontuk le:

Jelentős (több mint 50\%) $\mathrm{H}_{\mathrm{c}}$-csökkenést sikerült kimutatni a FINEMET típusú prekurzor ötvözet szerkezeti relaxációja alatti hőmérsékleten (300 ${ }^{\circ} \mathrm{C}$ alatt), anélkül, hogy a kristályosodás megindulna.

A hőkezelési hőmérséklet hozzájárulása domináns a $\mathrm{H}_{\mathrm{c}}$ értékének csökkentésében és az elridegedésben egyaránt.

Mindkét tulajdonságváltozásért egyedül a rövid távú atomi átrendeződések felelősek.

A hosszirányú, egytengelyű húzó mechanikai igénybevétel okozta feszültség hatása hasonló a hosszirányú mágneses mező hatásához a hőkezelés során; a koercitív erő $\left(\mathrm{H}_{\mathrm{c}}\right)$ csökkenése felgyorsul, ha a mágneses mezőben történő hevítést és a külső mechanikai feszültséget egyidejüleg alkalmazzák. 


\section{Köszönetnyilvánítás}

A közleményben bemutatott kutatást az Új Széchenyi Terv keretében az EFOP-3.6.1-16-2016-0003 és az EFOP-3.6.2-16-2017-00016 projektek részeként hajtották végre. A projekt befejezését az Európai Unió és az Európai Szociális Alap társfinanszírozza.

\section{Szakirodalmi hivatkozások}

[1] Makino M., Inoue A., Masumoto T.: Nanocrystalline Soft Magnetic F-M-B ( $M=Z r, H f, N b)$ Alloys Produced by Crystallization of Amorphous Phase. Materials Transactions JIM, 36/7. (1995) 924-938. https://doi.org/10.2320/matertrans1989.36.924

[2] Herzer G.: Nanocrystalline soft magnetic alloys. In: Handbook of Magnetic Materials. (Szerk.: Buschow K. H. J.) Elsevier Science, Amsterdam, 10/3. (1997) 415-462. https://doi.org/10.1016/S1567-2719(97)10007-5

[3] Lu K., Wang Y. Z., Wei W. D., Li Y. Y.: The temperature dependence of specific resistance for nanocrystalline alloys with different average grain size. Advanced Cryogenic Materials, 38. (1991) 285.

[4] Lu K.: Nanocrystalline metals crystallized from amorphous solids nanocrystallization, structure and properties. Materials Science and Engineering R., 16/4. (1996) 161-221. https://doi.org/10.1016/0927-796X(95)00187-5

[5] Scott M. G.: Crystallization in Amorphous Metallic Alloys. In: Butterworths Monographs in Materials (Szerk.: Luborsky F. E.) Butterworth \& Co (Publishers) Ltd., London, 1983. 144-168.

[6] Lovas A., Kiss L. F., Varga B., Kamasa P. Balogh I., Bakonyi I.: Survey of magnetic properties during and after amorphous-nanocrystalline transformation. Journal of Physics IV., 8/2. (1998) 291-298.

[7] Yamauchi K., Yoshizawa Y.: Recent development of nanocrystalline soft magnetic alloys. NanoStructured Materials, 6. (1995) 247-254.

https://doi.org/10.1016/0965-9773(95)00048-8

[8] Yoshizawa Y., Yamauchi K.: Effects of magnetic field annealing on magnetic properties in ultrafine crystalline $\mathrm{Fe}$-Cu-Nb-Si-B alloys. IEEE Transactions on Magnetics, 25/5. (1989) 3324-3326. https://doi.org/10.1109/20.42291

[9] Ayers J. D., Harris V. G., Sprague J. A., Elam W. T., Jones H. N.: A model for nucleation of nanocrystals in the soft magnetic alloy $\mathrm{Fe}_{73.5} \mathrm{Nb}_{3} \mathrm{Cu}_{1} \mathrm{Si}_{13.5} \mathrm{~B}_{9}$. NanoStructured Materials, 9. (1997) 391-396. https://doi.org/10.1016/S0965-9773(97)00091-3

[10] Hono K., Ping D.H., Ohnuma M. Onodera H.: $\mathrm{Cu}$ clustering and Si partitioning in the early crystallization stage of an $\mathrm{Fe}_{73.5} \mathrm{Si}_{13.5} \mathrm{~B}_{9} \mathrm{Nb}_{3} \mathrm{Cu}$ amorphous alloy. Acta Materiala, 47/3. (1999) 997-1006.

https://doi.org/10.1016/S1359-6454(98)00392-9

[11] Lovas A., Kisdi-Koszó É., Konczos G., Potocky L., Vértesy G.: Casting of ferromagnetic amorphous ribbons for electric and electrotechnical applica- tions. Philosopical Magazine B, 61. (1990) 549565.

[12] Varga B., Lovas A., Ye F., Gu X. J., Lu K.: Pressure dependence of nanocrystallization in amorphous $\mathrm{Fe}_{86} \mathrm{~B}_{14}$ and $\mathrm{Fe}_{85} \mathrm{Cu}_{1} \mathrm{~B}_{14}$ alloys. Materials Science and Engineering: A, 286. (2000) 193-196. https://doi.org/10.1016/S0921-5093(00)00634-1

[13] Lindqvist P. A., Uhrenius B.: On the Fe-Cu phase diagram. Calphad, 4/3. (1980) 193-200.

[14] Lovas A., Kiss L. F., Balogh I.: Saturation magnetization and amorphous Curie point changes during the early stage of amorphous-nanocrystalline transformation of a FINEMET-type alloy. Journal of Magnetism and Magnetic Materials, 215-216. (2000) 463-465.

https://doi.org/10.1016/S0304-8853(00)00189-X

[15] Kovac J., Novák L., Hubac L.: Impulse annealing as possibility of modification of magnetic properties of amorphous metallic alloys. Journal of Electrical Engineering, 66/7s. (2015) 142-145.

[16] Mehrer H.: Diffusion in Solids - Fundamentals, Methods, Materials, Diffusion-Controlled Processes. 1. kiadás. Springer-Verlag, Berlin-Heidelberg, 2007.

[17] Gerling R., Wagner R.: Properties of in-core reactor-irradiated amorphous $\mathrm{Fe}_{40} \mathrm{Ni}_{40} \mathrm{~B}_{20}$. Journal of Nuclear Materials, 107. (1982) 311-317. https://doi.org/10.1016/0022-3115(82)90430-5

[18] Herzer G.: Nanocrystalline soft magnetic alloys. In: Handbook of Magnetic Materials. (Szerk.: Buschow K H. J.) Elsevier Science, Amsterdam, 10/3. 1997. 415-462.

[19] Hubas L., Novak L., Balla S., Lovas A.: Evolution of magnetic and mechanical properties in FINEMET-type precursor glasses during isothermal and pulse heat treatments. Acta Physica Polonica A, 131/4. (2017) 672.

https://doi.org/10.12693/APhysPolA.131.672

[20] Weltsch Z., Klam K., Lovas A.: Comparison of hardness and coercivity evolution in various $\mathrm{Fe}-\mathrm{B}$ based glasses (including FINEMET precursos) during relaxation and crystallization. Acta Physica Polonica A, 131/4. (2017) 669. https://doi.org/10.12693/APhysPolA.131.669

[21] Lovas A., Kisdi-Koszó É., Potocky L., Novák L.: Effect of processing conditions on physical properties of transition metal-metalloid metallic glasses. Journal of Materials Science, 22. (1987) 1535-1546.

https://doi.org/10.1007/BF01132372

[22] Cohen M. H., Grest G. S.: Liquid-glass transition, a free volume approach. Physical Review B, 20. (1979) 1077.

https://doi.org/10.1103/PhysRevB.20.1077

[23] Tsai-Wei Wu, Spaepen F.: The relation between embrittlement and structural relaxation of an amorphous metal. Philosofical Magazine B, 61/4. (1990) 739-750.

https://doi.org/10.1080/13642819008219307 